\title{
Crossroads of Global and Local Identity in Contemporary Latvian Migrant Literature: Reflections on the Novel Stroika with a London View by W. B. Foreignerski (V. Läcìtis)
}

\author{
OJĀRS LĀMS
}

\begin{abstract}
This paper deals with the contemporary migration experience as seen through the subjective lens of a literary text. The analysis focuses on the novel Stroika ${ }^{1}$ with a London View by the Latvian diaspora writer William B. Foreignerski (Vilis Lācītis in the Latvian version). Foreignerski combines the portrayal of proletarians' survival with entertaining and comical scenes from daily life. In the novel the story is told from the perspective of the narrator in the first person singular, thus the different relationships between the protagonist and the surrounding environment are already defined by this choice.

In the novel the image of London is of great significance as a metropolis and multicultural city in which most of the events described in the novel occur. London is the key determinant for the poetics of intercultural literature in the novel - London can be a labyrinth, an initiation, a trap or a springboard. London as a city that can provide everything that life can offer gives one a chance not only to break away from the economic limitations at home but also from the ideological narrowness of the protagonist's homeland as it is depicted in the novel. The start of the quest for a new life at the beginning of the novel is to a certain extent traumatic as it is characteristically in traditional emigrant literature. However, with the intercultural approach used by Foreignerski, the migration experience results in the freedom to accept new ideas and in gaining new horizons for the protagonist as well as for the reader.
\end{abstract}

Keywords: identity; Latvian contemporary migration literature; W. B. Foreignerski (V. Lācītis); London; translation and adoption

1 Stroika - a slang word from Russian meaning 'a building site'

DOI: https://doi.org/10.12697/IL.2019.24.2.4 


\section{Introduction}

The involvement of Latvia in European integration has produced a new type of Latvian diaspora. The dynamic processes of its formation and existence are reflected in Latvian literature, albeit not massively. Migration narratives, in which various cultures and experiences interact, have brought about a new type of texts. The few novels, short stories and plays published and performed so far have elicited a lively response in Latvian readers and belong to a set of texts actively promoted for translation and international distribution by publishers. Particularly salient texts are the following: Šampinjonu derība (The Mushroom Testament, 2002), a novel by Laima Muktupāvela (1962); Stroika ar skatu uz Londonu (Stroika with a London View, 2010), the phenomenally successful debut novel by Vilis Lācitis (1975) who for the English version² changed his Latvian nom de plume 'Vilis Lācìtis' to the internationally more acceptable William B. Foriegnerski; the novels Dzimtenite (Moonshine, 2012) by Andra Manfelde (1973) and most recent reflections on the migrants' life by Alvils Bergs (1958) Divi stāsti par Barsu (Two Stories about Barca, 2018) and by Oskars Tarvids Viesstrādnieka dienasgrāmata (Diary of a Gastarbeiter, 2019). The novels focus on economic migrants to the UK and Ireland, but stories by Alvils Bergs deal with the millennial generation who is free of the Soviet legacy and enjoys the benefits of EU open borders. However, migration brings insecurity and trauma, generating nostalgia.

The new Latvian migrant literature is different from the classical examples of the migrant narratives in that it takes place within an open and globalized world and that the characters preserve their links and bonds with the country of origin, frequently travelling to it.

Cultural interaction and conflicts, integration efforts, trauma, adapting to life in a multicultural megapolis create the essential dimensions of contemporary migration literature. A comparative introduction into Latvian migration is given by Ojārs Lāms and Dens Dimiņš in the journal Trames (Lāms \& Dimiňs 2019: 189). This study will focus on the characteristics of the novel by W. B. Foreignerski Stroika with a London View. Due to its translation into English, the novel is available to the international readership and the text is a very characteristic literary manifestation of contemporary migration processes. This paper will deal with the migration experience through the subjective lens of a literary description, mixed with the ideology of true globalization.

2 The English version was made by the author himself, adapting the Latvian text for the international readership. 
William B. Foreignerski or Vilis Lācītis - a double pseudonym of a single author

The actual name of Vilis Lācītis is Aleksandrs Rugèens (born in 1975). His debut novel Stroika with a London View is based on his own experience. It became very popular with readers and got a high ranking from professionals for novelty. After his brilliant debut, Lācìtis continued his literary work, publishing further novels about contemporary Latvian migration (Pamodināt Lāčplēsi / To Wake up the Bearslayer, 2011, Amsterdamas princips / The Principle of Amsterdam, 2013), a collection of short stories Sekss un vardarbiba (Sex and Violence, 2018) and others but the success of the debut novel has not been repeated.

The author of Stroika with a London View uses his pseudonym as a powerful tool for addressing readers but it also reflects his somewhat diffuse identity.

The Latvian version of Stroika with a London View was published in 2010 under the pseudonym Vilis Lācitis, which speaks volumes to the Latvian readership. The pseudonym contains several layers of meaning for the Latvian reader. Lācitis is a diminutive of the word 'lācis' ('bear' in Latvian). It is a common method to form surnames in Latvian with the help of diminutives (many Latvian surnames are diminutives), but at the same time this particular surname is quite unusual and would rather be given to a children's toy - a teddy bear. Thus, already the pseudonym conveys a certain air of lightness and playfulness and the author tries to retain this atmosphere in his narrative in which the protagonist not always encounters the easiest of situations. The pseudonym contains another dimension that in a way makes this playfulness problematic with its load of cultural references and reminiscences - in Latvian literature there was a writer called Vilis Lācis (1904-1966) who was a popular author of pulp fiction in the pre-Second World War era and he wrote novels about self-made men, thus affirming the value of progress and self-development, and inspiring large masses of readers. These motifs occur in Lācitis's novel as well. But in 1940, during the Soviet occupation, Vilis Lācis became a symbol of national betrayal - he became the leader of the puppet government and signed documents for the deportation of people to Siberia. Vilis Lācitis constructs his protagonist in a fashion similar to the heroes of Vilis Lācis, but his hero is the more nonchalant one, without a clearly defined purpose, more of a Fortune's darling. It is clear that this very Latvian pseudonym in English translation makes no sense, so Aleksandrs Rugêens looked for a different strategy. He made the book cover look like an advertisement, supplementing two keywords Stroika and London with a third - the name of the author which implicitly shows narrative construction and by association reflects the negatives stereotypes 
about Gastarbeiters in the British society. The name B. Foreignerski has associations with the expression 'a bloody foreigner'. On the cover page the wordplay hidden in the nome de plum is explained:

William B. Foreignerski, as his name suggests, is a foreigner. He came to the UK to find work, earn a pound and then leave. Instead he learned the local language and stayed, charmed by the country and its people.

Is he again for the economy? Read the book and decide yourself. (Foreignerski 2019: 1)

When addressing English readers, the author identifies himself simply as a foreigner. To Latvians the text was offered as a Latvian adventure story in the unknown Western world the symbol of which is London. For some of the migrants London can be a trap or a labyrinth where they lose their way but the protagonist reflects the author's way and it is a way to a new open-minded and globalized intercultural identity.

\section{London as a Global Identities Fair}

The action of the novel takes place in London, except some short chapters where for a while the protagonist moves to Ireland and back to his homeland.

London and Latvia, a city and a country that are quite far apart from each other in geographical terms but in the global context in the 21st century and the search for one's identity as an Eastern European these places become constituent parts of a new geo-political and consequently literary paradigm when the former imperial metropolis that already has a diverse multicultural experience becomes a mother or step-mother to ethnical groups that historically might not have been part of the British Empire, especially those of Eastern Europe and Latvians among them. The integration into the western world of Eastern Europeans has a significant side-effect - the movement of people in the search of a better job and life. Great Britain with its need for labor and accordingly soft immigration policy in the early 21 st century was very expedient for Eastern Europeans and thus became one of the main destinations for seekers of a better life. London as one of the European meccas of multiculturalism rapidly obtained Eastern European features and today can be considered an important Eastern European city as well. London is a peculiar concentrate of possibilities and challenges and a special kind of litmus test for the self-confidence of an Eastern European. It is possible to generalize 
Crossroads of Global and Local Identity in Contemporary Latvian Migrant Literature

the opinion of the social anthropologist Michał Garapich when he speaks about Poles in London:

British pragmatism and the free market make it possible for migrants to perceive the British Isles as the fulfilment of their dreams of a genuine meritocracy. [...] London appears so attractive $[\ldots]$ because the number of potential encounters, human relationships, life-course scenarios, life-changing events, etc. is nearly infinite. [...] with many Polish migrants we find a curious mixture of fatalism and individualism, of the conviction that luck is the determining factor and the belief that in London, it is sufficient to want to work in order to gain esteem and money. (Garapich 2010: 72)

Although the communities at the new location are based on ethnic and linguistic properties, a common mentality from the socialist past creates a wider cultural group of Eastern Europeans. This multi-dimensional structure of belonging that is in some aspects common to all Eastern Europeans is mentioned by Foreignerski at the beginning of his novel in an episode where the protagonist sails away from his homeland's misfortunes. On the ship he meets a fellow countryman, an experienced emigrant, who sketches in broad strokes the main features of the life of an immigrant from Eastern Europe. This experienced emigrant Pete says: "You must find an Eastern European colony, and - that's all. What do you mean by that - that's all? - I asked. That's it means that's. You don't need anything else. They will find you a job, and you won't have any problems with the language. Mate, I'm totally fine with the Russian lingo anywhere in the world because all our folks - well, our ex-folks, from the Soviet-influenced territories - you know what I mean - they all speak Russian.” (Foreignerski 2019: 17). London is emerging as a huge multicultural, multilingual fair.

The integration of Eastern Europeans into London's both specifically British and universally multicultural milieu has found considerable echoes in the literature of Eastern Europe in general, and Foreignerski's novel is a good example. London and the events taking place there are a great source for stories that are era-specific and thus leave scope for generalization. London is an indicator, an environment with its own diversity, akin to a labyrinth and when the exit from this labyrinth is successfully found, it becomes an initiation, when not it becomes a trap. Somehow London is an analogy of the whole world. The Argentinian writer Jorge Luis Borges has noted: “There's no need to build a labyrinth when the entire universe is one. For the man who truly wants to hide himself, London is a much better labyrinth than a rooftop room to which every blessed hallway in a building leads.” (Borges 1998: 261) 
With its equivocal character, constantly changing atmosphere and diversity, London vividly equates the relationship between a human being and the world. Nonetheless it is not the London about which Samuel Johnson has said, "Why, Sir, you find no man, at all intellectual, who is willing to leave London. No, Sir, when a man is tired of London, he is tired of life; for there is in London all that life can afford." (Boswell [1791], s.p.) London offers everything that life can offer but the meaning and content of these two notions has become somewhat vague and obscure. It is not always a valuable experience, for some it can be a trap where all hopes are shattered. Foreignerski points to the gap dividing the West from the East and thus his novel has a thoroughly dramatic setting. The protagonist confronts life's trials which are presented with a touch of joyfulness and ridicule. Since the novel was first published, some important geopolitical changes have taken place, namely the refugee crisis that has added a different nuance to the question of migration. But the essence remains the same nonetheless - the spoilt Western society cannot exist without immigrants and this migration is multi-layered. Western society is paying its dues for its former imperialism and Eurocentric arrogance.

\section{Deconstruction and reconstruction of the self-made-man concept}

The presence of Russian slang in the title (stroika - an unfinished building still in the process of being built) indicates the social milieu and is a parody of the heritage of Vilis Lācis who introduced into Latvian literature the self-made man who was later recast as the builder of communism when Vilis Lācis became a Soviet collaborationist. Despite the comical re-coding, it carries a note of bitterness. Thus, that traumatic era is brought in indirectly yet deconstructed light-heartedly. London gains an inverted meaning - it is a chance to get away not only from the economic hardship but from the ideological traps at home. Despite the irony, the construction of the narrator-protagonist relies heavily on the conception of man found in the works of V. Lācis where the protagonist experiences misfortune due to a caprice of Fate but does not give up his struggle for a better place in society. It is a bourgeois success-story although the author endeavors to position himself as an apostle of freedom, an enlightened individual not bound to the system but at the end he is just a reflection of that system. The author and the protagonist both want to study at Cambridge and do so. They also become global-minded which for them means "cultural and mental changes that come from the inside and are not imposed by outsiders" (Foreignerski 2019:178). Yet Vilis Lācītis also continues to be a quite prolific 
Crossroads of Global and Local Identity in Contemporary Latvian Migrant Literature

Latvian author writing about cultural differences and inteculturality who now lives in England.

\author{
Ojārs Lāms \\ ojars.lams@lu.lv \\ Latvijas Universitāte \\ Visvalža 4A \\ LV-1004 Riga \\ LATVIJA / LATVIA
}

\title{
References
}

Berelis, G. 2010. Vilis Lācītis "Stroika ar skatu uz Londonu”. Berelis vērtē, https:// berelis.wordpress.com/2010/12/10/vilis-lacitis-stroika-ar-skatu-uz-londonu/ (01. 06.19).

Berelis, G. Literatūras gada balva 2010. Finālisti. Vilis Lācītis: „...caur reg̣ipša putekḷiem mans cel̦š̀”. - https://berelis.wordpress.com/2011/05/17/literaturasgadabalva-2010-finalisti-vilis-lacitis-caur-regipa-putekliem-mans-cel/ (01.06.19).

Borges, J. L. 1998. Ibn-Hakam al-Bokhari, Murdered in His Labyrinth. - J. L. Borges, Collected Fictions. New York: Penguin Books, 255-262.

Boswell, J. [1791.] Life of Johnson, Vol. 3, 1776-1780. Ed. by George Birckbeck Hill. Kindle Edition.

Foreignerski, W. B. 2019. Stroika with a London View. London: Austin Macauley Publishers.

Garapich, M. 2010. Die Nomaden Europas - Polnische Migranten in der Risikogesellschaft'. - Jahrbuch Polen 2010. Migration. Transl. from Polish into German by Ulrich Heisse. Ed. Andrzej Kaluza and Jutta Wierczimok. Wiesbaden: Harrassowitz, 65-77.

Lācītis, V. 2010. Stroika ar skatu uz Londonu. Rīga: Mansards

Lāms, O. 2016/2017. Starpkultūru literatūra. Viḷa Lācīša romāns Stroika ar skatu uz Londonu. - Akadèmiskā Dzìve, 53, 32-37.

Lāms, O., Dimiņš, D. 2019. Latvians down and out in England and Ireland: Contemporary Migration Tales. - Trames. 23(73/68), 2, 189-202. https://doi.org/10.3176/ tr.2019.2.05

Laurušaite, L. 2008. Baltu trimdas romāns - piedāvājums un pieprasījums. - Aktuālas problēmas literatūras zinātnē. Liepāja: LPA, 172-182.

Laurušaitè, L. 2015. The imagological approach to Lithuanian and Latvian contemporary émigré narratives. - Interlitteraria, 20/1, 68-181. https://doi.org/10.12697/ IL.2015.20.1.13

Plesske, N., Rostek, J. 2013. Rubble or Resurrection: Contextualising London Literature by Polish Migrants to the UK. The Literary London Journal, Volume 10 Number 2 (Autumn 2013), http://www.literarylondon.org/londonjournal/ autumn2013/plesskeandrostek.html (01.06.19). 